Стеван Б. БРАДИТ ${ }^{*}$

Универзитет у Новом Саду

Филозофски факултет
Оригинални научни рад

Примљен: 15. 11. 2016.

Прихваћен: 10. 02. 2017.

\title{
ПОЕЗИЈА У ЕСЕЈИСТИЦИ И ЕСЕЈИСТИКА У ПОЕЗИЈИ: ХИБРИДИЗАЦИЈА ЖАНРА ЕСЕЈА У ДЕЛУ ВОЈИСЛАВА ДЕСПОТОВА
}

\begin{abstract}
Познато је да је неоавангарда једнако као и историјска авангарда експериментисала са различитим формама књижевног стваралаштва. У овом раду обрађује се специфично хибридно стапање жанра есеја и спева у делу конкретистичког песника Војислава Деспотова. У методолошком смислу рад се ослања на концепцију уметничких режима Жака Рансијера и анализе жанра есеја Теодора Адорна и Михаила Епштејна. Излажући трансформације у пољу модерне књижевности, у одликама Деспотовљевог спева препознаје се покушај излагања целовитости друштвене стварности, док се у одликама есеја открива фрагментаризација и аналитичност која никада не прелази у чисту апстракцију. На овај начин показује се како дати жанрови, захваљујући својим контрадикторним карактеристикама, адекватно сведоче о постмодерној стварности. Деспотовљев књижевни текст се тако смешта у друштвеноисторијску стварност, чије механизме његов лирски субјект покушава да разоткрије и критички сагледа.
\end{abstract}

Кључне речи: спев, есеј, уметнички режим, постмодерно стање, еманципација.

У маневру који би, можда, наишао на одобравање класичних филолога и филозофа, почео бих од варијације једног питања постављеног у античкој Грчкој: зашто уопште постоји жанр, а не просто књижевност ${ }^{1}$ Наше разматрање хибридизације жанра есеја у Деспотовљевом песништву морамо, дакле, започети од питања дискурзивне границе, јер уколико жанр не постоји, не постоје ни поезија, ни проза, ни драма, ни есејистика. Да бисмо одговорили на постављено питање морамо се окренути историји, будући да садашње стање књижевног поља, како у светској тако и у српској књижевности, јесте последица дуготрајног кретања различитих језичких пракси.

Наш задатак, међутим, није да анализирамо само заснивање жанровског погледа на књижевност, већ да у складу са предметом, одредимо релевантан

\footnotetext{
"stevan.bradic@fff.uns.ac.rs

${ }^{1}$ У питању је, наравно, варијација Парменидовог питања „Зашто је уопште биће а не ништа?”, које се може разумети и као један од оснивачких исказа западне метафизике.
} 
историјски оквир. У најширем смислу можемо га пронаћи у слому класицизма, или онога што савремени француски филозоф Жак Рансијер назива репрезентативним режимом уметности, а који је, према његовом мишљењу, уз извесне просторне и временске прекиде био доминантан од антике до краја 18. века. ${ }^{2}$ Начин на који ће одређени актери бити подражавани у простору видљивог, разумљивог и делатног у овом режиму је строго опосредован жанровским процедурама и представама, које су подржавале и обнављале доминантну поделу чулности. ${ }^{3}$ Читава ова конструкција се урушава доласком романтизма, током кога се формира естетски режим, у коме се „уметнички феномени идентификују путем њиховог поклапања са специфичним режимом чулности" (Рансијер 2004: 22). Његова појава није ништа друго до појава књижевности у модерном смислу речи, као језичке уметничке праксе. Прелазак на естетски режим може се описати кроз обрт свих основних принципа репрезентативног, у коме, наравно, не долази до укидања жанровске поделе, већ до реинтерпретације самог значења жанра. То, између осталог, значи да уместо жанровске хијерархије представљања, наступа једнакост свих представљених предмета, као и да стил постаје индиферентан према датим предметима. Роман се често наводи као парадигматски пример оваквог разумевања књижевности, будући да своја правила, у априорном поетичком смислу, до данас није пронашао, остајући у извесном смислу ,жанр без жанра" (Рансијер 2011: 50), па би модерно доба било доба романа. ${ }^{4}$ За нашу је анализу од пресудног значаја да у естетском режиму постају могуће, као уметничке чињенице: мешање жанрова, слободни стих и песма у прози, преплитање различитих уметности, колаж, перформанс, ready-made, фотографија, филм итд., односно, тек са естетским режимом постаје могуће преплитање поезије и есеја, и Деспотовљев „есејистички спев” „Неочекиван човек” (2002 [1992]).

Важно је пре свега запазити да се (ироничним) поднасловом ово дело, поред есеја, одређује и као спев, односно не као лирска већ као епска творевина. Спев припада класичној поетици и у одређеној мери опстаје још у периоду романтизма, али и ту већ у различитим жанровским хибридиза-

\footnotetext{
${ }^{2}$ Како Рансијер запажа, репрезентативни режим уноси расцеп у платонистичко схватање техничке вештине препознајући „специфичну суштину уметности у пару poiesis mimesis” (2004: 21). У овом режиму, четири приниципа уређивала су начин на који ће се одређена делатност успоставити уметничко стваралаштво: „примарност фикције, жанровска природа представљања дефинисана и уређена према предмету представљања, примереност средстава представљања и говор у акцији као идеал" (Рансијер 2011: 49).

${ }^{3}$ Подела чулности је средишњи појам политичког мишљења Жака Рансијера. Њоме се одређује „ко може имати удео у заједничком заједнице на основу онога што ради, као и на основу времена и места у којима се његова делатност одвија” (Рансијер, 2004: 12). Она је „подела простора и времена, видљивог и невидљивог, говора и буке, која истовремено одређује место и улоге политике као облика искуства" (Исто: 13).

${ }^{4}$ Класицизам је роман безуспешно покушавао да смести у такозвани средњи стил, али будући да је од самог почетка нестабилан, он је у непрестаној потрази за сопственим правилима, као и лик Дон Кихота у истоименом Сервантесовом роману. Управо је то разлог зашто модерна књижевност и уметност уопште, као уметност прозе и прозног света, не може да се самопревазиђе, као што је Хегел тврдио - у недостатку априорне поетике не може се ни формулисати становиште које је потребно превазићи.
} 
цијама (филозофски спев, роман у стиховима и сл). Спев, као епска врста, у традиционалном смислу сведочи о јединству обичајне свести која кроз њега саму себе доживљава у језичкој форми. Илијада и Одисеја су парадигматски спевови Запада, и Рансијер нам показује како се крајем 18. века обликује схватање према коме је човек на самим ,зачецима” културе кроз њих успостављао одређену језичку мрежу којом је осмишљавао сопствено искуство и свет који га окружује. ${ }^{5}$ Ово је један од разлога филозофског и политичког интересовања за епско песништво, али и књижевност уопште. У датом контексту песници су могли да покушају да створе нову „митологију духа”, која би пружила нови „органски” основ заједници, различит од економске прорачунатости модерног доба. ${ }^{6}$ Наводна хармонија класичног спева, али и других форми класичне уметности, одиграва се на нивоу света, језика, колектива и индивидуе, али она припада друштву које претходи подели рада, тако да је његова судбина истовремено и судбина спева: превазиђеност. Спев се показао као неадекватна форма естетске праксе у свету који је драматично промењен у односу на контекст у коме се она први пут јавила.

Упркос томе Деспотовљев спев заиста претендује да сведочи о модерној људској заједници, не само заједници чије је „органско јединство” нарушила подела рада, већ о „постмодерној” заједници, односно заједници позног капитализма, како је назива Фредерик Џејмсон. ${ }^{7}$ Наслови циклуса сведоче нам о његовој тематици: „Календарска хистерија”, „Производња нове природе”, „Централни парк и замењени свет”, „Неочекиван човек”, „Случајна прокреација”, „Доступни свет”, „Државна носталгија”, „Табеле будућности”, „Баук истополаца”, „Предузећа за задовољење нагона”, „Страст и анархија конт-

\footnotetext{
${ }^{5}$ Рансијер ће запазити како се човек, према овој интерпретацији, улазећи у језички однос са светом, самопроизвео као биће разумевања, али тако да овај прелаз није био појмовно филозофски, већ песнички, зато што су изворни гестови којима је човек одређивао ствари ,изворне фигуре уметности, поезије и реторике” (Рансијер 2011: 58). Викоово разумевање песништва почива на историзацији кретања мишљења, али не као апстрактне самосвести, већ као објективног духа, дакле, као начина на који се свест обликује у друштвене институције и норме заједничког живота. Песници су у том смислу сагледани као први законодавци људске заједнице, тако што кодификују одређене облике понашања изговарајући их у спевовима.

${ }^{6}$ Ова митологија угледала се на антички свет и покушавала је да пронађе замену за хомеровски спев (као слику јединства духа обичајне заједнице) у роману као адекватној форми модерног доба. Хегел, међутим, показује да ово више није могуће јер спев није наивно песништво, као што су они сматрали, већ се налази између „првог” језика и модерног света - он говори о стварности која више не постоји и зато је песничка утопија, а не стварно стање ствари.

${ }^{7}$ Џејмсон наводи следеће: „Постмодерне теорије [...] личе на оне амбициозне социолошке генерализације које, истовремено, доносе вести о инаугурацији читавог новог типа друштва, чувено крштеним као 'постиндустријским' (Данијел Бел), али често називаним и конзумеристичким, медијским, информацијским, електронским, високотехнолошким итд. Такве теорије имају очигледну идеолошку мисију указивања да нове друштвене формације више не зависе од закона класничног капитализма, односно примарности индустријске производње и класне борбе. Марксистичка традиција им се зато жестоко опирала, са посебним изузетком економисте Ернеста Мендела, чија студија Позни капитализам, показује не само анатомију историјске оригиналности новог типа друштва (које види као трећу етапу или моменат у еволуцији капитала) већ и да је оно ако ништа друго управо чистији облик капитализма него сви они који су му претходили [...] сваки став о постмодернизму у култури - било одбрана било напад - је такође, и нужно, имплицитно или експлицитно политички став о природи мултинационалног капитализма данас" (Џејмсон 1991: 3).
} 
расветова”, „Пацифички супермен и европски машинист”, „Панк и производња историје”, „Срећа у кавезу”, „Нуклеаристичка култура” и „Мит новог умирања". Крећући се са сопственим историјским контекстом, он изговара форме чулности које препознаје као парадигматске за неку претпостављену целину. У њему се на луцидан начин сагледава постмодерни „субјект”, „субјект” друштва позног капитализма, са свим својим апоријама и идентитетима, који се остварују у виду различитих друштвених супкултура, попут хипи комуна, религиозних секти, ЛГБТ заједнице итд. Специфичан статус у односу на њих има и питање националног идентитета, које је у контекстуалном смислу било изузетно значајно у време настајања збирке. Деспотов се у овом тексту чак упушта и у неку врту песничког „законодавства”, односно у предвиђање будућности, у циклусу „Табеле будућности”, дајући нацрт према коме треба да се одвија светско историјско кретање. Видљиво је, дакле, да се ослања на одређену традицију коју спев са собом доноси.

Истовремено, овај жанровски избор делује необично, будући да је јасно како се обичајна јединственост објективног духа у модерном добу тешко може обновити. Можда би се његово оправдање могло пронаћи у поетичкој вертикали која од романтизма, преко авангарде води до неоавангарде, у којој се Деспотов обликује као песник, и поставангарде у којој пише свој „спев”. Авангардисти су једнако као и романтичари у књижевности видели могућност друштвене трансформације, која је водила кроз проналажење нових форми. Овај захтев био је истовремен са захтевом за преображајем, а потом и укидањем саме институције уметности кроз њено идентификовање са свакодневним животом. Чини се, међутим, да Деспотовљев спев не прелази читав спектар овог кретања.

Можемо се зато запитати: шта је уопште од спева остало у његовом тексту? Он је подељен у тематске циклусе, написане слободним стихом, који нису обједињени заједничким наративом, који немају заплет или протагонисте, већ само фигуре и проблеме, о којима сведоче. Сматрам да је управо у овоме видљива хибридизација спева са жанром есеја. Метод представљања са којим се читалац сусреће у „Неочекиваном човеку” припада жанру есеја (наравно, уколико есеј уопште прихватимо као жанр). Како би ову тврдњу подробније образложили, скренућемо пажњу на анализу есеја коју нам доноси Теодор Адорно:

Gotovo da je samo esej realizovao sumnju o bezuvjetnom pravu metode u načinu postupanja mišljenja. Esej vodi računa o svijesti o neidentičnosti, a da to uopće ne izgovara; radikalan je u neradikalizmu, u suzdržavanju od svake redukcije na jedan princip, u akcentuiranju parcijalnog naspram totalnog, u djelomičnom (Адорно 1985: 23).

Адорнов исказ има двоструки значај: пре свега, есејистичка форма спева одговара модерној стварности, заједници која више не може да оствари непосредно јединство (иако се оно у различитим облицима обећава), док са друге стране, бројни партикуларни идентитети управо представљају његову садржину. Описана партикуларност есејистике једино и може да „адекватно” сведочи о свету који је и сам распарчан. Али морамо нагласити како ова пар- 
тикуларност није пука одлика модерности, већ је у Деспотовљевом случају одређена партикуларност, која настаје крајем шездесетих година двадесетог века и која се тиче уметничке колико и политичке форме.

Савремени француски филозоф Лик Фери тако тврди да је након Другог светског рата антагонистички моменат авангарде интегрисан у капиталистичку, масовну културу: „Побуна је постала поступак, реторичка критика, преступ - церемонија. Негација је престала да буде стваралачка" (Фери 1994: 193). ${ }^{8}$ Уместо да се јави као антибуржоаска, неоавангарда се, парадоксално, показала као крајњи израз друштва које је критиковала. Као врхунац и почетак престројавања неоавангардних покрета у правцу поставангарде, најчешће се наводи слом револуције 1968. године:

Сви они политички покрети којима је неоавангарда била уметничко средство исказивања - доживели су крах, осули су се у секте или у мале терористичке групе. У политичком смислу и са становишта самих покрета, већ су студентски немири током 1968-1970. наговестили крај неоавангарде и промену њене функције (Саболчи 1997: 158).

Из наведених Саболчијевих речи видимо да неоавангардна фрагментација није била уметничка стратегија, већ процес условљен историјским неуспехом, а како Питер Биргер запажа, „неуспех маја '68 најављен је [...] неуспехом [историјских авангарди]" (Биргер 2010: 711-712).

„Неочекиван човек”, говорећи о плурализму идентитета који, иако своје порекло имају у покушају превазилажења потрошачког друштва ипак бивају интегрисани у његове механизме, сведочи управо о овом неуспеху. Он је, као и Деспотовљева песма „Зашто мрзим хаику”, анатомија неуспеха неоавангарде. Форма ове анатомије је оксиморон: спев као одраз заједнице, есеј као одраз фрагментације. Он не почиње од онтолошких поставки нити се завршава на крајњим питањима (што је типично за форму есеја), већ од хоризонта ситуације у којој се налази: први циклус спева, „Календарска хистерија” говори о глобализацији и унификацији мерења времена, која је само наличје глобализације техничког мишљења, које омогућава кретање западног империјализма. Крајњи хоризонт ситуације обрађен је у последњем циклусу, „Мит новог умирања", у коме се говори о начину на који се савремени човек односи према сопственој коначности, тако што покушава да је припитоми, пре свега тако што ће је објаснити путем науке. Човекова ситуираност видљива је управо у начину на који живи довршење метафизике (и крај онтотеологије), одбијајући да сопственом постојању додели трансцендентну димензију, али остајући немоћан да саму смртност превазиђе. На овај начин Деспотов од есеја позајмљује стратегију демитологизације (Адорно 1985: 20), али се не

\footnotetext{
${ }^{8}$ Фери такође наводи и запажање америчког социолога Данијела Бела према коме супротстављеност авангарде и масовне културе ишчезава када се „шездесетих година [...] [распростире] морал аутентичности чији се категорички императив састоји у две речи: Be yourself" (према Фери 1994: 201). Бел инсистира да се у овом периоду: „супротност буржуја и уметника појављује [...] као парадоксално дејство новог лица индивидуализма [...] Отуда сукоб између једне економске сфере која [...] остаје регулисана старањем за рентабилношћу, и једне културне сфере која, под привидом радикалне критике потрошачког друштва у ствари само подстиче на потрошњу" (према Фери 1994: 202).
} 
одриче симболичког и имагинарног вишка који је конститутиван за постмодерну стварност - исписујући је као идеологију.

Нешто слично ће запазити и Михаил Епштејн, наводећи како је есеј укорењен у миту: „U stvari esej se usmerava na ono jedinstvo života, misli i slike koje je iskonski, u sinkretičkoj formi, ukorenjeno u mitu" (Епштејн 1997: 77). Али ситуација је далеко комплекснија и мит се овде може узети само у метафоричком смислу (синкретизам форми мишљења), будући да, као што смо видели, есеј не ствара митологију, али да код Деспотова то чини спев, док је есеј непрестано поткопава. Уместо мита, теолошке догме и филозофске апстракције, есеј индивидуалном придаје „онтологијски дигнитет” (Адорно 1985: 24). Али оно што видимо у Деспотовљевом спеву јесте да се управо овај дигнитет у постмодерном стању губи тако што се увлачи у потрошачку машинерију капитала. Деспотов то показује поступком који је такође типичан за есеј - дајући супстанцу искуству у оној мери у којој је филозофија даје категоријама. Чинећи то, он доводи у питање сваку деисторизацију феномена људског постојања - па и самог човека, крећући се трагом деконструкције, поглавито Фукоа (Ријечи и ствари). Човек је историјски произведен и временом ће се повући са историјске позорнице. Управо то је значење наслова овог спева, како аутор наводи у уводној белешци:

После много векова, противно свим пророчанствима, појављује се човек чија својства нису нипошто могла да буду предвиђена - неочекиван човек. Тај модерни човек ни сам не зна шта може да очекује од будућности [...] Он је неочекиван јер ни сопствену стварност, онакву каква је, није могао да очекује. Овај мој есејистички спев [...] је извештај о ентропији, неочекиваности, извештај о успону и паду нове природе (Деспотов 2002: 356).

Описујући неочекиваног човека, његов успон и пад, Деспотов још једном поступа есејистички, будући да „ne želi naći ono večito u prolaznome i izdestilirati ga, prije želi ovjekovečiti prolazno" (Адорно 1985: 24). Неочекиван човек управо је оно пролазно.

Коначно, можемо поставити питање: шта је то есеј добија поетизацијом, преносом, често механичким, у дикцију стиха који је повремено римован? Једноставан одговор би био - формалну надоградњу, која се може разумети као нешто спољашње есејистичком садржају. Са друге стране постоји извесна димензија коју есеј не подразумева иако се налази на граници уметничког говора: приступајући појединачном, он то чини аналитички, иако неконзистентно, користећи се фигурама скоро искључиво у реторичком смислу. Уметнички текст, међутим, слободан је да конструише отворену структуру тако да се задатак читаоца испуњава у парадигматском, а не само синтагматском повезивању. Деспотовљев текст нам, на одређеним местима, омогућава управо овакве читалачке гестове. Другим речима, у њему метафора није само стилска фигура која се може сусрести у овом или оном исказу, већ може да преузме читаву конструкцију. Одређени циклуси се онда могу читати у бенјаминовском смислу - као политичке алегорије.

Да бисмо видели како ово одиграва, довољно је да се осврнемо на циклус „Централни парк и замењени свет”. У њему се може пронаћи не само списак мноштва различитих идентитета који се јављају на Западу крајем 20. 
века, већ и једна врста тематизовања друштвене позорнице на којој су се они тек могли јавити, а која је смештена у Њујорк - ,једини светски град" (Деспотов, 2002: 365). Управо се дата тематизација може разумети као жанровска одлика спева. Овај циклус се концентрише на питање објективног духа, који се разлаже на два елемента, субјект и позорницу, али ћемо видети да и један и други заправо прикривају одсуство и једног и другог. ${ }^{9}$ Са друге стране, немогућност спева да се успостави као целовито сагледавање постмодерног доба надомешта се управо есејистичком некохерентношћу:

Esejizam je mešavina raznovrsnih nedostataka i nezavršenosti, koji neočekivano omogućavaju da se sagleda ona oblast celine koja odlučno uzmiče određenim žanrovima što imaju svoj ideal savršenstva (poema, tragedija, roman itd.), te zbog toga odbacuju sve što ne ulazi u njihove okvire (Епштејн 1997: 77).

У поменутом циклусу Централни парк се успоставља, фукоовски говорећи, као паноптички простор, којим се врши дисциплиновање субјеката тако што се у контексту постмодерног друштва то чини полицијским праксама, али и путем забаве. ${ }^{10}$ Он постаје простор двоструког отуђења - на првом месту сам град се отуђује од природе и уобличава у посебан, вештачки простор, чије произвођење служи акумулацији и дистрибуцији капитала, заступљеног на главним улицама, а потом се град отуђује од самог себе у простору парка, који постаје синтеза „неприродног” и „природног”, као обећање искупљења од насиља капитала. Тај потез, наравно, прикрива чињеницу да природа у парку заправо и не постоји већ да је само фикција која обезбеђује обнављање друштвеног поретка који се успоставља на главним улицама. Ову демистификацију природе можемо препознати као жанровску карактеристику есеја:

Esej bez riječi odbacuje iluziju da bi misao mogla provaliti iz onoga što je thesei, kultura, i dospjeti u ono što je physei, do prirode. Začaran onim što je izvedeno, što je fiksirano, tvorevinama, esej odaje prirodi počast time što potvrđuje da ona više ne postoji za čovjeka (Адорно 1985: 25).

Исти овај покрет припада кретању капитализма, како Харви примећује: „Урбанизам, 'градско планирање', јесте метод којим капитализам преузима контролу над читавим природним и људским окружењем” (2011: 5).

„Централни парк” зато можемо читати као политичку алегорију позног капитализма, простора руковођеног профитом који се регулише према сопственим (,природним”) законима, али који се заправо одржава и обнавља кроз имплицирани режим заснован на надзору и дисциплиновању, као и императиву ужитка. То је постмодерно стање у коме више нема великог наратива историје, еманципације која би била покретачки мотор, већ само контрадик-

9 У овом смислу ћемо се ослонити на концепцију „права на град” Дејвида Харвија, који детаљно говори о преображајима на плану урбанизма у Њујорку 20. века: „Град је човеков најуспешнији покушај да преобрази свет у коме живи према сопственим жељама. Али, како је град свет који је човек створио, он је постао свет на који је човек осуђен. На овај начин, индиректно, и без јасне свести о природи свог задатка, стварајући град човек је преобразио и самог себе" (Харви 2011: 4).

10 За детаљну анализу „Неочекиваног човека” видети: Брадић 2012: 119-160. 
ција које су профитабилне и које свој највиши израз задобијају у идеологији мултикултурализма. „Централни парк” је политичка алегорија која приказује фиксиране релације неједнакости, али и механизме којим се ова неједнакост обнавља и одржава. Чинећи то, он такође поступа као есеј: „Esej mora učiniti da u izabranom ili pogođenom potezu zasja totalnost, a da ne tvrdi kako je ona sveprisutna" (Адорно 1985: 30). Уколико је парк представљен као исијавање „хармоније” позног капитализма, текст који ово разоткрива покушава да изврши интервенцију у подели чулности и да дату „хармонију” поремети. Зато можемо да приметимо да је субјект текста и даље на позицијама еманципације и да његов спев има имплицитну критичку улогу, ма колико била прикривена иза ироније.

Есејистички спев, као хибридно стапање различитих жанрова је оксиморонско. Оно подразумева две сасвим супротстављене дискурзивне праксе, али се управо као такво показује примереним историјској ситуацији у којој настаје. Док спев са једне стране имплицира заједништво и рефлексију форми заједништва у језику, есеј подразумева партикуларизацију и методолошку некохерентност. Постмодерна стварност, уколико тако разумемо оно што „Неочекиван човек” описује, одговара у структурном смислу есејистичком начину говора, са бескрајним умножавањем идентитета и форми живота, док субјект/говорник „Неочекиваног човека” има претензију дистанце у односу на ову стварност. Његова дистанца може се историјски пратити и поетички извести из романтизма, мада је упутније да се позиционира у односу на авангарду и неоавангарду, дакле, пројекте који су имали експлицитну еманципаторну димензију. Након неуспеха ових покрета са краја шездесетих и почетка седамдесетих година 20. века, и њихови уметнички пројекти су доживели постепено гашење и прелазак у поставангардно, тј. постмодерно стање. Деспотовљев спој есеја и спева сведочи о једној врсти верности догађају авангарде и непристајању на новонасталу ситуацију. Он током осамдесетих престаје са конкретистичким песничким експериментисањем и уместо њега посеже за преиспитивањем неуспеха уметничке праксе у којој је и сам учествовао, тако што је позиционира у шири друштвеноисторијски контекст. За овако нешто неопходна му је есејистичка аналитичност и блискост искуству. Са друге стране, он остаје веран утопијском пројекту, у чему му помаже форма спева, као имплицитне могућности да се сагледа опосредована целина објективног духа и да се укаже на могућност њеног превазилажења. Празно место које руководи читавим овим текстом је одсуство или крах истинског догађаја, који би био процеп у подели чулности, о којој нам свим својим потезима сведочи. 


\section{ЛИТЕРАТУРА}

Адорно 1985: T. W. Adorno, Filozofsko-sociološki eseji o književnosti, Zagreb: Školska knjiga

Биргер 2010: P. Bürger, Avant-Garde and Neo-Avant-Garde: An Attempt to Answer Certain Critics of Theory of the Avant-Garde, New Literary History, No. 41, 695-715.

Брадић 2012: С. Брадић, Симулащија и гастрономија: режими чулности и аспекти идентитета у песништву Војислава Деспотова, Београд: Службени гласник.

Деспотов 2002: В. Деспотов, Сабране песме, Зрењанин: Градска народна библиотека „Жарко Зрењанин”.

Епштејн 1997: M. Epštejn, Esej, Beograd: Narodna knjiga - Alfa.

Рансијер 2004: Jacques Rancière, The politics of aesthetics: the distribution of the sensible, London: Continuum.

Рансијер 2011: Jacques Rancière, Mute speech, New York: Columbia University Press.

Саболчи 1997: М. Саболчи, Авангарда \& неоавангарда, Београд: Народна књига.

Фери 1994: Л. Фери, Ното Aestheticus: откриће укуса у демократском добу, Нови Сад: Издавачка књижарница Зорана Стојановића.

Харви 2011: Д. Харви, Право на град, Златна греда, год. 11, бр. 113/114 (март-април), 4-10.

Џејмсон 1991: F. Jameson, Postmodernism, or, The Cultural Logic of Late Capitalism, Durham: Duke University Press.

Stevan B. Bradić POETRY IN ESSAY WRITING AND ESSAY WRITING IN POETRY: HYBRIDISATION OF THE
ESSAY GENRE IN THE OPUS OF VOJISLAV DESPOTOV

(Summary)

It is well known that the neo avant-garde, as well as the historical avant-garde, experimented with different forms of literary expression. In this essay I analyze a specific hybrid intersection of two distinct genres, of epic and of essay, in the works of the concretist poet Vojislav Despotov. In methodological sense I rely on the conception of artistic regimes, as developed by contemporary French philosopher Jacques Rancière, as well as on the analysis of the genre of essay by Theodor Adorno and Mikhail Epstein. By explicating the transformations in the field of modern literature, I show how the characteristics of the epic in the works of Despotov represent an effort to encompass the totality of contemporary social reality, while the essayistic elements stand in for the fragmentation and the analytical attitude that never ascends to pure abstraction. In this manner I describe how these genres, precisely because of their contradictions adequately represent the postmodern reality. This is how Despotov's text positions itself within the social and historical reality, whose mechanism his speaker attempts to uncover and criticize. 